\title{
Information and communication technology (ICT) knowledge and skills of subject librarians at the university libraries of KwaZulu-Natal
}

\author{
Ruth Hoskins' \\ Information Studies, School of Sociology and Social Studies, University of KwaZulu-Natal, \\ hoskinsr@ukzn.ac.za
}

\begin{abstract}
Received: $19^{\text {th }}$ December 2003
Revised: $7^{\text {th }}$ February 2005

This article is based on part of a survey that investigated the ICT knowledge and skills of subject librarians at the university libraries of KwaZulu-Natal. A study population of 43 subject librarians, in the university libraries of the Universities of Durban-Westville, Natal (Durban and Pietermaritzburg), and Zululand were surveyed by means of a mailed questionnaire to establish in what ways subject librarians were using ICTs, what the level of ICT knowledge and skill was amongst the subject librarians, what problems the subject librarians faced in the use of ICTs and what their ICT training needs were. Interpretation of the results revealed a low level of ICT knowledge and skill amongst subject librarians and a general lack of formal training for ICTs amongst the subject librarians.
\end{abstract}

\section{Introduction and Problem Statement}

The subject librarian's role has changed rapidly in recent years, in response to new forms of information and new methods of teaching and learning. Increased student numbers have spread existing subject staff more thinly; widening modes of access have brought in more part time students; more student centred learning demands a greater variety of teaching skills; and the explosion of electronic information (from CD-ROM (Compact Disk Read Only Memory) to the Internet) requires continuous updating of knowledge and skills (Bluck 1996: 97). Convergence between libraries and computer centres may also broaden the academic liaison role to include the information communication technology (ICT) needs of students and staff.

Furthermore, user expectations of the ability of a library service to deliver high quality services are growing. Linked to user demands for services is the influence of information technology (IT). Students, for example, are becoming more computer literate and the academic library environment has changed substantially in the increased variety of technology used for service delivery. The subject librarian has become more of a consultant in information services and many users want to conduct some of their searches from their own workstations (Viljoen and Underwood 1997: 47). If users wish to be more independent in their search for information, user education in the use of information systems and databases is very important. Bluck (1996: 98) argues that:

...the changes due to new technology and information systems mean that all subject/information librarians will

be expected to master "navigational skills" to get through electronic databases and show others how to do so.

Also, continued financial constraints have placed greater pressure on collection development policies, and given impetus to the move towards networked information in electronic format. Therefore, for subject librarians to perform their roles effectively and efficiently in such a demanding electronic environment they will have to possess the necessary ICT knowledge and skills and therefore will have to be computer literate. Only then can they impart ICT skills to their users.

The purpose of the study was to investigate the ICT knowledge and skills of subject librarians at the university libraries of KwaZulu-Natal. The specific objectives of the study were to: investigate the ways in which the subject librarians were using ICTs, establish the level of ICT knowledge and skills amongst the subject librarians, identify problems the subject librarians faced in the use of ICTs and to identify the subject librarians ICT training needs.

\section{Review of the literature}

The review focuses on the definition of computer literacy, ICT skills requirements by librarians and the International Computer Driving Licence (ICDL).

\section{Defining computer literacy}

Computer literacy is highly context-dependent:

Computer literacy is the ability to use microcomputers confidently for obtaining needed information, solving specific problems, and performing data-processing tasks. This includes a fundamental understanding of the operation of microcomputers in general, as well as the use of several types of application software packages (Van Vliet, Kletke and Chakraborty 1994: 838).

I. Ruth Hoskins is a lecturer at the University of KwaZulu-Natal Pietermaritzburg.. 
In this definition, the ability to use microcomputers confidently means that a person has the ability to respond via keyboard, and perhaps a mouse, to questions or other types of communication that might be part of a software programme. The fundamental understanding of microcomputer operations in general includes a basic comprehension of an operating system and the ability to perform routine tasks such as looking at directories of diskettes or copying a file. Application packages that are now part of the computer literate persons repertoire are word processors, spreadsheets, and perhaps, database management systems.

\section{ICT and the academic library}

Academic librarianship is purported to have changed more over the last few decades than in its entire previous history. The factors affecting such change may be divided into four categories: economics, technological, higher education and organisational (Farley, Broad-Preston and Hayward 1998: 238). The wide spread use of ICT in libraries, and especially the development and access to digital information resources via the Internet, has raised a number of challenges and concerns for librarians. These include the impact of ICT on the role of librarians and the resulting need for new skills and competencies suitable for the digital information environment. According to Chisenga and Rorissa (200I: 5) the role of librarians in the digital information environment is evolving. Librarians are now being expected to possess skills and expertise, in addition to the traditional library and information management skills specifically in the use of ICT, electronic publishing, digital information management and knowledge management.

Technological changes have resulted in librarians constantly questioning their future and the competencies they will need to survive professionally (Woodsworth 1997: 46). Job advertisements today give some clues as to the skills required. A study conducted by Zhou (1994) which investigated the market change regarding the demand for computer literacy for librarians in academic and public libraries in the United States from 1974 to 1989, revealed that computer applications have changed in many aspects the ways by which libraries provide services. As a result, computer literacy has gradually become an important competency for librarians in many positions.

Woodsworth (1997) suggests that technological competencies are the most critical ones for all librarians, even if they obtained their professional credentials as recent as the early 1990s. Basic competencies for librarians must include knowing what the Internet is and is not; evaluating and using hardware, software, and networks; and understanding basic computer and information science concepts. According to Marmion (1998: 216) the biggest technology challenge facing the library profession today is that of preparing our employees to use technology effectively. To meet this challenge, libraries must pay much more attention to technology training and computer skills than they traditionally have in the past. Computers, connectivity, and electronic information are redefining the library profession and what librarians do. According to Latham (2000) technical literacy is no longer a specialty but a survival skill for all librarians. While this skill rapidly obtained a name, "computer literacy", little consensus has been developed on precisely what set of abilities it actually represents.

\section{Which ICT related skills do librarians need?}

Krissof and Konrad (1998: 29) argue that for librarians or users to consider themselves truly information literate in this day and age, it is essential that they develop both traditional literacy skills and fundamental computer literacy skills. Latham (2000: 4l-42) argues that every librarian should be familiar with all components of an office suite: word processing, spreadsheets, databases, and scheduling programmes. Further, librarians should be able to choose the appropriate application for the anticipated result, that is, a database for lists repeating the same type of information, spreacisheets for tracking numerical data, word processing for forms, for instance. Library staff, for that matter, should be able to make use of the extended capabilities of an application: to create charts, import graphics, and attach files, and so forth. They should know what is attached to their CPU, and how it is attached, and they should be able to perform basic troubleshooting functions: power source, monitor adjustments, reboots, printer response, and how to write down error messages.

All librarians should be familiar with installing, configuring, and using a browser and should be able to discuss intelligently their favourite search engines on the Web and explain why they use each one. Librarians should also be able to discuss when a Web search is preferable to a print search, and vice-versa. Every librarian should be familiar with e-mail and its more sophisticated functions; folders, sorting to folders, address books, attachments, groups, v-cards, for instance. Beyond the functionality, however, we need to look at ways to use e-mail to expand communications within the organisation, particularly large organisations. Due to the penetration of standards, all staff should be familiar with whichever version of Windows is run within the organisation, how to navigate through Windows (with and without a mouse), and how to manage files associated with Windows (Latham 2000: 42). Also, every librarian should be familiar with not only the functions of the public access workstations but the care and maintenance of those installations 
hardware as well as software. Librarians should have a basic understanding of their institutional network design, LANs, and WANs, so that they can perform a minimal level of intelligent troubleshooting (Latham 2000: 42).

Librarians who are Webmasters need to have a working knowledge of HTML (Hyper Text Markup Language), tables, browsers, graphic placement, CGI (Common Gateway Interface) programming, UNIX and Java (Saunders-McMaster 1997: 37). The challenge facing libraries is to get their librarians up to speed and to master the tools they use in working with electronic information. According to Marmion (1998: 217) while many individuals, and even some institutions are already there, as a profession librarianship is not. Many research libraries, even, are not. Ongoing training is necessary if today's libraries are to keep up with changing technology:

The goal of virtual library staff training and support should be the creation of a staff capable of creating, maintaining, and expanding virtual libraries; capable of constant learning or 'retooling'; and most importantly, capable of imaginative innovation, without which today's cutting-edge virtual library will be tomorrow's actual disaster (Marmion 1998: 217).

According to Krissoff and Konrad (1998) how do librarians provide good training for library users when librarians themselves are being overwhelmed by change? This implies that librarians will be failing those they serve if they do not acquire computer skills. One solution lies in information agencies making a formal commitment to staff computer and technology training. Librarians, as instructors and trainers, must develop the confidence and computer competencies necessary to make intelligent decisions about what their users need to know and about effective strategies for teaching those skills. By putting themselves first in the electronic information age, librarians stand a much better chance of continuing to provide the levels of service to which they, as a profession, have historically aspired. In the study upon which this article is based the International Computer Driving Licence (ICDL) was seen to incorporate the knowledge and skills most typical of the ICT competencies required of subject librarians in Higher Education.

\section{The International Computer Driving Licence (ICDL)}

The ICDL is proof of the ability to use a computer and its most popular applications.

It is an international standard for assessing computer literacy. The ICDL is an end-user standard out-and-out test. No programming is taught. Candidates have to pass tests in each of the seven modules, and the level of competency is high. To obtain the ICDL a candidate must demonstrate practical proficiency in each of the most commonly used software tools. The candidate has to pass all seven modules at a high level, in some cases as high as $80 \%$. The standards for the ICDL have been set jointly by the major European Computer Societies. Worldwide the European Computer Driving Licence Foundation administers the ICDL. In Southern Africa the Computer Society of South Africa (CCSA), that has established the ICDL Foundation for South Africa for this purpose, administers it (Computer Society of South Africa 2002). Most international organisations, technikons and universities in South Africa give recognition and credit for the ICDL.

\section{The ICDL syllabus}

The ICDL syllabus consists of seven module domains:

I.Basic concepts of information technology

2.Using the computer and managing files

3.Word processing

4.Spreadsheets

5.Database

6.Presentation

7.Information and communication (ECDL Foundation 1999: 6-7).

\section{Training and testing centres for the ICDL in KwaZulu-Natal}

Once a candidate has passed all seven modules they obtain a Skills Card, which is sent to the ICDL Foundation who issues the International Computer Driving Licence Certificate. The following tertiary institutions in KwaZulu-Natal were training centres: the University of Natal (UN) (University of Natal Durban and Pietermaritzburg) and University of Zululand. These universities provided training not just for their staff but also for the general public (Computer Society of South Africa 2002).

\section{Methodology}

The study covered the four university libraries in KwaZulu-Natal, which belonged to the esAL (Eastern Seaboard Association of Libraries) consortium. Other academic and research libraries such as the college and technikon libraries in the province, which were also members of esAL, were excluded from the study, as including them would have been too large a task for the requirements of the level of research that was undertaken. The study targeted subject librarians and the technology investigated was limited to the use of personal computers. 
The population consisted of 43 subject librarians at the four university libraries:

I.Six at the University of Durban-Westville (UDW);

2.14 at the University of Natal Durban (UND);

3.10 at the University of Natal Pietemaritzburg (UNP); and

4.13 at the University of Zululand (UZ).

The small size of the population made sampling unnecessary.

A self-administered questionnaire was used for collecting the data. The self-administered questionnaire was designed to establish the ICT knowledge and skills of subject librarians at the university libraries of KwaZulu-Natal. The questionnaire consisted of II sections was designed to establish general information about the subject librarians as well as specific information relating to their ICT knowledge and skills. Questions (a) to ( $f$ ) of Section I asked the respondents for background information such as the university library in which they worked, age, gender, professional qualifications and duties or tasks of their work.

Questions (h) to (o) of Section I dealt with general computer usage and more importantly whether the respondents had an ICDL. Sections 2 to 9 were based on the ICDL syllabus modules. These sections were as follows:

I.Section 2: File management

2.Section 3: Windows / keyboard

3.Section 4: Word processing

4.Section 5: Spreadsheets

5.Section 6: Databases

6.Section 7: Presentations

7.Section 8: E-mail

8.Section 9: Internet

Questions in each of these sections tested the respondent's knowledge and skills regarding their performance of specific operations. Questions relating to training and the problems respondents had with each section or application were also included. Sections 4 to 9 asked respondents to list the software they used for each section. The following sections 10 and II, although they do not fall within the scope of the ICDL syllabus were included on the basis of their importance, which was established in the literature review.

I.Section 10: Networking

2.Section II: Set-up, maintenance and troubleshooting

Most of the questions in the data-gathering instrument were closed or limited option questions. In this study closed questions, which forced the respondents to choose between a "yes", "no" and "uncertain" option were used.

The instrument was pre-tested on three lecturers from the Information Studies Discipline at the School of Human and Social Studies, University of Natal Pietermaritzburg, to examine the clarity, content validity, and relevance of the questions. These lecturers were chosen because they were all professional librarians who worked at an academic institution.

Once the design of the questionnaire had been completed and checked, a copy of the covering letter and the questionnaire were mailed to members of the population using the lists of names and addresses that were obtained from the deputy librarians of the UDW, UND and UZULU. Since the researcher was a subject librarian at the UNP Library it was not necessary to obtain the names and addresses of the other subject librarians at the UNP Library. The cover letter explained the purpose of the study briefly, while the front page of the questionnaire included the instructions on how to complete the questionnaire. The internal mail service between UDW and the UN campuses allowed respondents to return the completed questionnaires via the internal mail service. The UZULU respondents, where given a stamped selfaddressed envelope and returned their completed questionnaires via the regular postal services.

The response rate was initially low and only 17 questionnaires were completed and returned by the due date. Therefore, the deadline for completing the questionnaire was extended by one week. Of the 43 copies of the questionnaires that were sent out 31 were returned, yielding a response rate of $72 \%$. This relatively high response rate for a mailed questionnaire is possibly explained by the fact that some of the questionnaires were delivered in person to members of the study population. Also, contact was made with certain individuals in each university's subject librarian unit and these individuals returned the questionnaires to the researcher.

The type of data collected, the purpose for which the study was conducted, and to meet the study's objectives determined the methods for data analysis. A coding key was prepared in which numerical values were assigned to all limited answer options in the questionnaire. The data was entered on a data matrix designed using SPSS. The data relating to limited option questions was then processed in terms of frequency counts and percentages. Content analysis, done manually, was used to interpret the responses to open questions. 


\section{Results and discussion}

In line with the intentions of the research the results are reported under broad headings for the demographics of the population and each of the objectives of the study.

\subsection{Demographics of the population}

The most commonly held qualification was the bachelor of Library Science Honours degree held by 21 (33.9\%). A Higher Diploma in Library Science was held by 15 (24.2\%) with the equivalent Bachelor of Library Science degree held by nine ( $14.5 \%)$ and the Advanced University Diploma in Library and Information Studies held by four (6.5\%). Masters degrees were held by six (9.7\%) with a Master of Library Science degree and two (3.2\%) with the equivalent Bachelor of Library Science Masters degree. Diplomas were held by three (4.8\%) with a National Diploma in Library Science and two (3.2\%) a Postgraduate Diploma in Information Management.

More than half of the subject librarians (22 or 73.3\%) had obtained their qualifications during the years 1990-1999, with $16(51.6 \%)$ in the decade 1980-1989. Followed by four (12.9\%) in 1970-1979 and one (2.3\%) in 1960-1969 and 2000 or there after.

Linked to the subject librarian's level of performance is the formal training they received. Of the subject librarians ( 16 or $50 \%$ ) had obtained their library qualifications from 1990 to 1999 . The other (16 or 50\%) obtained their library qualification from 1969 to 1989 . With academic libraries undergoing major changes in the last 10 years due to technological developments, the literature clearly argues that technological competencies are the most critical ones for librarians, even if they obtained their professional qualifications as recent as the early 1990s (Woodsworth 1997). Therefore, $50 \%$ of the subject librarians would have received their library education at a time when technological competencies were not as critical as they are now, thus suggesting that they might not have the appropriate knowledge and skills. However, it could be argued that a further degree in the form of an Honours or Masters degree could have remedied this. However, as mentioned already only half the subject librarians held an Honours or Masters degree in library and information studies. Also, this presupposes that the Honours or Masters degree curriculum made provision for ICT knowledge and skills education. Thus, further skilling in the form of ongoing training and, or continuing education would be imperative for subject librarians to keep pace with the many technological changes in the library and information field.

\subsection{The ways in which the subject librarians were using ICTs}

\subsection{Home computer use}

Most of the subject librarians (22 or $71 \%$ ) had access to a home computer, while nine (29\%) did not. These home computers were used for word processing (16 or 50\%), Internet access (6 or $15.8 \%)$, e-mail ( 5 or I3.2\%), games ( 3 or $7.9 \%$ ), spreadsheets ( 2 or $5.3 \%$ ) and file management; compiling bibliographies; presentations (I or $2.6 \%$ ).

\subsubsection{Work computer use}

A majority of the subject librarians (29 or $93.5 \%)$ used a computer in the course of their duties or tasks at work, while two $(6.5 \%)$ did not. Subject librarians used a work computer for database searching ( 22 or $73.3 \%$ ), information retrieval (21 or $71 \%)$, word processing (17 or $54.8 \%$ ), e-mail (16 or $51.6 \%$ ), Internet access (15 or $48.4 \%)$, classification; cataloguing (9 or $29 \%$ ), user education (7 or $22.6 \%$ ), presentations (4 or $12.9 \%)$, spreadsheets; data capture (3 or $9.7 \%$ ), Web page construction (2 or $6.5 \%$ ), Webct programmes (I or 3.2\%). Almost all the subject librarians (30 or $96.8 \%$ ) had their own work computer, except one (3.2\%) of the respondents who shared a computer with colleagues.

Since computers have assumed a central role in the library profession over the past years, most of the subject librarians used a computer to perform their tasks and duties. Therefore to perform their tasks and duties efficiently, subject librarians must have the necessary ICT knowledge and skills.

\subsection{The level of ICT knowledge and skills amongst the subject librarians}

\subsection{ICDL}

The ICDL was held by three (9.7\%) of the subject librarians. Most of the subject librarians ( 25 or $80.6 \%)$ did not have an ICDL. Also, 22 (7I\%) of the subject librarians did not know whether their institution gave recognition and credit for the ICDL qualification while only $16(51.6 \%)$ of the subject librarians were aware of their institutions providing training for the ICDL.

The three subject librarians who had an ICLD performed well on all the sections of the questionnaire. The level of competency for the ICDL is high but commensurate with the knowledge and skills to be expected in terms of the subject librarians' requisite levels of professional expertise as was reflected in the literature. The subject librarians' performance on each section of the questionnaire that related to the ICDL revealed that generally there was a lack of ICT knowledge and skill when compared with the high level of competency that is required for the ICDL. 


\subsubsection{File management functions and operations}

Table I Functions relating to file management $\mathrm{N}=3$ I

\begin{tabular}{|c|c|c|c|c|c|c|c|c|}
\hline \multirow[b]{2}{*}{ FUNCTION } & \multicolumn{2}{|c|}{ No } & \multicolumn{2}{|c|}{ Yes } & \multicolumn{2}{|c|}{ Uncertain } & \multicolumn{2}{|c|}{ No response } \\
\hline & Count & $\%$ & Count & $\%$ & Count & $\%$ & Count & $\%$ \\
\hline Copy a file from & I & $3.2 \%$ & 29 & $93.5 \%$ & 1 & $3.2 \%$ & & \\
\hline Move around directories & 2 & $6.5 \%$ & 28 & $90.3 \%$ & 1 & $3.2 \%$ & & \\
\hline Copy a file onto & 2 & $6.5 \%$ & 28 & $90.3 \%$ & 1 & $3.2 \%$ & & \\
\hline Use virus checker & 3 & $9.7 \%$ & 28 & $90.3 \%$ & & & & \\
\hline Save a file & 4 & $12.9 \%$ & 27 & $87.1 \%$ & & & & \\
\hline Identify drives & 2 & $6.5 \%$ & 26 & $83.9 \%$ & 2 & $6.5 \%$ & I & $3.2 \%$ \\
\hline Name files & 5 & $16.1 \%$ & 23 & $74.2 \%$ & 2 & $6.5 \%$ & I & $3.2 \%$ \\
\hline Locate files & 3 & $9.7 \%$ & 23 & $74.2 \%$ & 5 & $16.1 \%$ & & \\
\hline Create a directory & 4 & $12.9 \%$ & 22 & $71 \%$ & 5 & $16.1 \%$ & & \\
\hline Search for files & 9 & $29 \%$ & 17 & $54.8 \%$ & 5 & $16.1 \%$ & & \\
\hline
\end{tabular}

The majority of the subject librarians could copy a file from a drive (29 or $93.5 \%$ ), move around directories; use the virus checker; copy a file onto a drive ( 28 or $90.3 \%)$. While $27(87.1 \%)$ could save a file, $26(83.9 \%)$ identify drives, 23 (74.2\%) name files; locate files ( 22 or $71 \%$ ) and create a directory and $17(54.8 \%)$ search for files.

\subsubsection{Windows and keyboard functions and operations}

Table 2 Functions relating to windows and keyboard $\mathrm{N}=3 \mathrm{I}$

\begin{tabular}{|c|c|c|c|c|c|c|c|c|}
\hline \multirow[b]{2}{*}{ FUNCTION } & \multicolumn{2}{|c|}{ No } & \multicolumn{2}{|c|}{ Yes } & \multicolumn{2}{|c|}{ Uncertain } & \multicolumn{2}{|c|}{ No response } \\
\hline & Count & $\%$ & Count & $\%$ & Count & $\%$ & Count & $\%$ \\
\hline Use mouse & & & 31 & $100 \%$ & & & & \\
\hline Double-click and drag & & & 31 & $100 \%$ & & & & \\
\hline Identify icons & & & 31 & $100 \%$ & & & & \\
\hline Select, open icon & & & 31 & $100 \%$ & & & & \\
\hline Maximise and minimise & & & 31 & $100 \%$ & & & & \\
\hline Open an application & & & 31 & $100 \%$ & & & & \\
\hline Retrieve document-floppy disk & & & 31 & $100 \%$ & & & & \\
\hline Retrieve a document- hard disk & & & 31 & $100 \%$ & & & & \\
\hline Name document & & & 31 & $100 \%$ & & & & \\
\hline Save document & & & 31 & $100 \%$ & & & & \\
\hline Exit from application & & & 31 & $100 \%$ & & & & \\
\hline Use scroll bars & & & 30 & $96.8 \%$ & I & $3.2 \%$ & & \\
\hline Re-name document & & & 30 & $96.8 \%$ & I & $3.2 \%$ & & \\
\hline Edit, re-save document & & & 30 & $96.8 \%$ & 1 & $3.2 \%$ & & \\
\hline Work with more than one application & & & 30 & $96.8 \%$ & 1 & $3.2 \%$ & & \\
\hline Use control panel & & & 29 & $93.5 \%$ & 2 & $6.5 \%$ & & \\
\hline Activate, deactivate window & & & 28 & $90.3 \%$ & 3 & $9.7 \%$ & & \\
\hline Copy document & & & 28 & $90.3 \%$ & 3 & $9.7 \%$ & & \\
\hline Create folders & 1 & $3.2 \%$ & 28 & $90.3 \%$ & 2 & $6.5 \%$ & & \\
\hline Save, open folders & & & 28 & $90.3 \%$ & 2 & $6.5 \%$ & 1 & $3.2 \%$ \\
\hline Identify what keys for & 3 & $9.7 \%$ & 27 & $87.1 \%$ & 1 & $3.2 \%$ & & \\
\hline
\end{tabular}

All of the subject librarians ( 3 lor 100\%) were able to use a mouse; click and drag; identify icons; select open icon; maximise and minimize; open an application; retrieve document-floppy disk; retrieve document-hard disk; name document; save document; exit from application, and 30 (96.8\%) were able to use scroll bars; re-name document; edit, re-save document and work with more than one application. While 29 (93.5\%) could use control panel, 28 (90.3\%) activate, deactivate window; copy document; create folders; save, open folders and $27(87.1 \%)$ identify what keys were for. 


\subsubsection{Word processing functions and operations}

Table 3 Functions relating to word processing $N=31$

\begin{tabular}{|c|c|c|c|c|c|c|}
\hline \multirow[b]{2}{*}{ FUNCTION } & \multicolumn{2}{|c|}{ No } & \multicolumn{2}{|c|}{ Yes } & \multicolumn{2}{|c|}{ Uncertain } \\
\hline & Count & $\%$ & Count & $\%$ & Count & $\%$ \\
\hline Open file & & & 31 & $100 \%$ & & \\
\hline Copy, move text & & & 31 & $100 \%$ & & \\
\hline Save a file & & & 31 & $100 \%$ & & \\
\hline Close a file & & & 31 & $100 \%$ & & \\
\hline Create file & & & 30 & $96.8 \%$ & I & $3.2 \%$ \\
\hline Change font size & & & 30 & $96.8 \%$ & I & $3.2 \%$ \\
\hline Change font style & & & 30 & $96.8 \%$ & I & $3.2 \%$ \\
\hline Use Save As & & & 30 & $96.8 \%$ & I & $3.2 \%$ \\
\hline Type formatted document & & & 29 & $93.5 \%$ & 2 & $6.5 \%$ \\
\hline Change line spacing & & & 29 & $93.5 \%$ & 2 & $6.5 \%$ \\
\hline Use spell checker & 2 & $6.5 \%$ & 29 & $93.5 \%$ & & \\
\hline Set margins & & & 27 & $87.1 \%$ & 4 & $12.9 \%$ \\
\hline Add columns & 2 & $6.5 \%$ & 27 & $87.1 \%$ & 2 & $6.5 \%$ \\
\hline Use thesaurus & । & $3.2 \%$ & 26 & $83.9 \%$ & 4 & $12.9 \%$ \\
\hline Add clipart & 2 & $6.5 \%$ & 26 & $83.9 \%$ & 3 & $9.7 \%$ \\
\hline Use dictionary & 2 & $6.5 \%$ & 25 & $80.6 \%$ & 4 & $12.9 \%$ \\
\hline Insert date, time, page no. & 1 & $3.2 \%$ & 25 & $80.6 \%$ & 5 & $16.1 \%$ \\
\hline Create header or footer & 3 & $9.7 \%$ & 24 & $77.4 \%$ & 4 & $12.9 \%$ \\
\hline Set tabs & 1 & $3.2 \%$ & 23 & $74.2 \%$ & 7 & $22.6 \%$ \\
\hline Open document without a .doc & 4 & $12.9 \%$ & 20 & $64.5 \%$ & 7 & $22.6 \%$ \\
\hline
\end{tabular}

All of the subject librarians ( 3 I or 100\%) could open file; copy, move text; save a file; close a file; create a file; while 30 (96.8\%) could change font size; change font style; use save as, 29 (93.5\%) type formatted document; change line spacing; use spell checker. While 27 (87. I\%) could set margins; add columns, 26 (83.9\%) use thesaurus; add clipart, 25 (80.6\%) use dictionary; insert date, time, page number, 24 (77.4\%) create header or footer, $23(74.2 \%)$ set tabs and $20(64.5 \%)$ open document without a document extension. Subject librarians responded to all the questions relating to word processing functions and operations.

4.3.4.I Word processing software

Microsoft Word was used by 22 (7I.8\%) of the subject librarians, while $9(28.2 \%)$ used Corel WordPerfect. 4.3.5 Spreadsheet functions and operations

Table 4 Functions relating to spreadsheets $\mathrm{N}=31$

\begin{tabular}{|c|c|c|c|c|c|c|c|c|}
\hline \multirow[b]{2}{*}{ FUNCTION } & \multicolumn{2}{|c|}{ No } & \multicolumn{2}{|c|}{ Yes } & \multicolumn{2}{|c|}{ Uncertain } & \multicolumn{2}{|c|}{ No response } \\
\hline & Count & $\%$ & Count & $\%$ & Count & $\%$ & Count & $\%$ \\
\hline Enter data & 7 & $22.6 \%$ & 22 & $71 \%$ & 2 & $6.5 \%$ & & \\
\hline Interpret info. in spreadsheet & 10 & $32.3 \%$ & 17 & $54.8 \%$ & 4 & $12.9 \%$ & & \\
\hline Create rows, coulmns, headings & 10 & $32.3 \%$ & 17 & $54.8 \%$ & 3 & $9.7 \%$ & 1 & $3.2 \%$ \\
\hline Insert into a word processing & 13 & $41.9 \%$ & 15 & $48.4 \%$ & 3 & $9.7 \%$ & & \\
\hline Create lables and values & 12 & $38.7 \%$ & 14 & $45.2 \%$ & 5 & $16.1 \%$ & & \\
\hline Copy using fill down or across & 14 & $45.2 \%$ & 14 & $45.2 \%$ & 2 & $6.5 \%$ & 1 & $3.2 \%$ \\
\hline Create a graph & 16 & $51.6 \%$ & 14 & $45.2 \%$ & 1 & $3.2 \%$ & & \\
\hline Format a cell or range & 12 & $38.7 \%$ & 13 & $41.9 \%$ & 6 & $19.4 \%$ & & \\
\hline Insert columns and rows & 15 & $48.4 \%$ & 13 & $41.9 \%$ & 3 & $9.7 \%$ & & \\
\hline Create a formual using functions & 16 & $51.6 \%$ & 11 & $35.5 \%$ & 4 & $12.9 \%$ & & \\
\hline Copy formulae using fill down or across & 16 & $51.6 \%$ & 11 & $35.5 \%$ & 4 & $12.9 \%$ & & \\
\hline Use gridlines, headers, footers & 18 & $58.1 \%$ & 11 & $35.5 \%$ & 2 & $6.5 \%$ & & \\
\hline Use text features for label cells & 17 & $54.8 \%$ & 11 & $35.5 \%$ & 3 & $9.7 \%$ & & \\
\hline Protect a cell or range & 16 & $51.6 \%$ & 10 & $32.3 \%$ & 5 & $16.1 \%$ & & \\
\hline Use hiding, freezing/splitting & 19 & $61.3 \%$ & 10 & $32.3 \%$ & 2 & $6.5 \%$ & & \\
\hline Create a formula using indicator & 16 & $51.6 \%$ & 7 & $22.6 \%$ & 8 & $25.8 \%$ & & \\
\hline Understand order of operations & 18 & $58.1 \%$ & 6 & $19.4 \%$ & 6 & $19.4 \%$ & 1 & $3.2 \%$ \\
\hline
\end{tabular}


Most of the subject librarians ( 22 or $71 \%$ ) could enter data followed by $17(54.8 \%)$ who could interpret information in spreadsheet; create rows, columns, headings. Less than half 15 (48.4\%) could insert into a word processing document, $14(45.2 \%)$ create labels and values; copy using fill down or across; create a graph, 13 (4I.9\%) format a cell or range; insert columns and rows. While II (35.5\%) could create a formula using functions; create formulae using fill down or across; use gridlines, headers, footers; use text features for label cells, 10 (32.3\%) protect a cell or range; use hiding freezing/splitting, seven $(22.6 \%)$ create a formula using indicator symbols and six $(19.4 \%)$ understand order of operations.

\subsubsection{Spreadsheet software}

Microsoft Excel was used by 26 (84\%) of the subject librarians, while 5 (16\%) used Corel Quattro Pro.

\subsubsection{Database functions and operations}

Table 5 Functions relating to databases $\mathrm{N}=31$

\begin{tabular}{lccccc}
\hline & \multicolumn{2}{c}{ No } & \multicolumn{2}{c}{ Yes } & \multicolumn{2}{c}{ Uncertain } \\
\cline { 2 - 6 } \multicolumn{1}{c}{ FUNCTION } & Count & $\%$ & Count & $\%$ & Count \\
\hline Enter data & 29 & $93.5 \%$ & 2 & $6.5 \%$ \\
Add a record & 29 & $93.5 \%$ & 2 & $6.5 \%$ & \\
Delete a record & 29 & $93.5 \%$ & 2 & $6.5 \%$ & \\
Sort records & 29 & $93.5 \%$ & 2 & $6.5 \%$ & \\
Search using "and", "or" or "not" & 29 & $93.5 \%$ & 2 & $6.5 \%$ & \\
Create multiple fields & 29 & $93.5 \%$ & 2 & $6.5 \%$ & \\
Create layout report & 29 & $93.5 \%$ & 2 & $6.5 \%$ & \\
Insert files into word processing documents & 29 & $93.5 \%$ & 2 & $6.5 \%$ & $3.2 \%$ \\
Create layout to match form & 29 & $93.5 \%$ & 1 & $3.2 \%$ & 1 \\
Create report with summaries & 29 & $93.5 \%$ & 1 & $3.2 \%$ & 1 \\
\hline
\end{tabular}

Only two (6.5\%) of the subject librarians could enter data; add a record; delete a record; sort records; search using "and", "or" or "not"; create multiple fields; create layout report; insert files into word processing documents. Similarly, only one (3.2\%) could create layout to match form and create report with summaries.

\subsubsection{Database software}

Microsoft Access was used by 23 (75\%) of the subject librarians, while eight (25\%) used Q + A.

\subsubsection{Presentation functions and operations}

Table 6 Functions relating to presentations $\mathrm{N}=31$

\begin{tabular}{|c|c|c|c|c|c|c|c|c|}
\hline \multirow[b]{2}{*}{ FUNCTION } & \multicolumn{2}{|c|}{ No } & \multicolumn{2}{|c|}{ Yes } & \multicolumn{2}{|c|}{ Uncertain } & \multicolumn{2}{|c|}{ No response } \\
\hline & Count & $\%$ & Count & $\%$ & Count & $\%$ & Count & $\%$ \\
\hline Add text and images & 9 & $29 \%$ & 21 & $67.7 \%$ & & & 1 & $3.2 \%$ \\
\hline Duplicate text and images & 8 & $25.8 \%$ & 21 & $67.7 \%$ & 1 & $3.2 \%$ & I & $3.2 \%$ \\
\hline Duplicate a slide & 8 & $25.8 \%$ & 21 & $67.7 \%$ & 1 & $3.2 \%$ & I & $3.2 \%$ \\
\hline Use cut and paste to move a slide & 8 & $25.8 \%$ & 21 & $67.7 \%$ & 1 & $3.2 \%$ & 1 & $3.2 \%$ \\
\hline Rotate or flip an object & 8 & $25.8 \%$ & 21 & $67.7 \%$ & 3 & $9.7 \%$ & । & $3.2 \%$ \\
\hline Change attributes, colour of shapes & 8 & $25.8 \%$ & 21 & $67.7 \%$ & 3 & $9.7 \%$ & 1 & $3.2 \%$ \\
\hline Apply shadow to shape & 7 & $22.6 \%$ & 21 & $67.7 \%$ & 2 & $6.5 \%$ & 1 & $3.2 \%$ \\
\hline Create organisational chart & 8 & $25.8 \%$ & 21 & $67.7 \%$ & 3 & $9.7 \%$ & 1 & $3.2 \%$ \\
\hline Preview using various views & 9 & $29 \%$ & 21 & $67.7 \%$ & & & I & $3.2 \%$ \\
\hline Choose automatic slide layout format & 9 & $29 \%$ & 20 & $64.5 \%$ & 1 & $3.2 \%$ & I & $3.2 \%$ \\
\hline Re-order slides & 8 & $25.8 \%$ & 20 & $64.5 \%$ & 3 & $9.7 \%$ & 1 & $3.2 \%$ \\
\hline Create different kinds of charts & 10 & $32.3 \%$ & 20 & $64.5 \%$ & 3 & $9.7 \%$ & & \\
\hline Number slides & 9 & $29 \%$ & 20 & $64.5 \%$ & & & 2 & $6.5 \%$ \\
\hline Modify organisational chart & 9 & $29 \%$ & 19 & $61.3 \%$ & 2 & $6.5 \%$ & 2 & $6.5 \%$ \\
\hline Add notes to slides & 10 & $32.3 \%$ & 18 & $58.1 \%$ & 2 & $6.5 \%$ & 1 & $3.2 \%$ \\
\hline Use master slide & 9 & $29 \%$ & 17 & $54.8 \%$ & 4 & $12.9 \%$ & 1 & $3.2 \%$ \\
\hline Add forms of shape & 8 & $25.8 \%$ & 17 & $54.8 \%$ & 2 & $6.5 \%$ & I & $3.2 \%$ \\
\hline Add preset animation effects & 11 & $35.5 \%$ & 17 & $54.8 \%$ & 2 & $6.5 \%$ & 1 & $3.2 \%$ \\
\hline Start a slide on any show & 11 & $35.5 \%$ & 17 & $54.8 \%$ & 2 & $6.5 \%$ & 1 & $3.2 \%$ \\
\hline Hide slides & 11 & $35.5 \%$ & 16 & $51.6 \%$ & 3 & $9.7 \%$ & 1 & $3.2 \%$ \\
\hline Use on-screen navigation & 11 & $35.5 \%$ & 15 & $48.4 \%$ & 4 & $12.9 \%$ & 1 & $3.2 \%$ \\
\hline
\end{tabular}


Only 2 I (67.7\%) of the subject librarians could add text and images; duplicate text and images; duplicate a slide; use cut and paste to move a slide; rotate or flip an object; change attributes, colour, shapes; apply shadow to shape; create organisational chart; preview using various views. While 20 (64.5\%) could choose automatic slides layout format; reorder slides; create different kinds of charts; number slides, 19 (61.3\%) modify organisational chart, 18 (58.1\%) add notes to slides, $17(54.8 \%)$ use master slide; add forms of shape; add preset animation effects; start a slide on any show and $16(51.6 \%)$ hide slides. Less than half ( 15 or $48.4 \%)$ could use on screen navigation.

\subsubsection{Presentation software}

Microsoft PowerPoint was used by 28 (90\%) of the subject librarians, while three (10\%) used Corel Presentations.

\subsubsection{E-mail functions and operations}

Table 7 Functions relating to e-mail $\mathrm{N}=31$

\begin{tabular}{|c|c|c|c|c|c|c|}
\hline \multirow[b]{2}{*}{ FUNCTION } & \multicolumn{2}{|c|}{ No } & \multicolumn{2}{|c|}{ Yes } & \multicolumn{2}{|c|}{ Uncertain } \\
\hline & Count & $\%$ & Count & $\%$ & Count & $\%$ \\
\hline Compose send e-mail & & & 31 & $100 \%$ & & \\
\hline Retrieve read e-mail & & & 31 & $100 \%$ & & \\
\hline Reply, forward e-mail & & & 31 & $100 \%$ & & \\
\hline Save, print, delete e-mail & & & 31 & $100 \%$ & & \\
\hline Open an attached file & & & 31 & $100 \%$ & & \\
\hline Attach a file & & & 30 & $96.8 \%$ & 1 & $3.2 \%$ \\
\hline Create manage folders & 2 & $6.5 \%$ & 28 & $90.3 \%$ & I & $3.2 \%$ \\
\hline File e-mail messages & 1 & $3.2 \%$ & 28 & $90.3 \%$ & 2 & $6.5 \%$ \\
\hline Subscribe to list/listserv & 5 & $16.1 \%$ & 23 & $74.2 \%$ & 3 & $9.7 \%$ \\
\hline
\end{tabular}

All of the subject librarians (3I or 100\%) could compose and send e-mail; retrieve, read e-mail; reply, forward e-mail; save, print, delete e-mail; open an attached file. While 30 (96.8\%) could attach a file, $28(90.3 \%)$ create and manage files; file e-mail messages and $23(74.2 \%)$ subscribe to list/listserv.

\subsubsection{E-mail software}

Novell GroupWise was used by 19 (6I.3\%) of the subject librarians, while 4 (I2.9\%) used Pixie, $3(9.7 \%)$ used Netscape Messenger and one (3.2\%) Outlook Express.

\subsubsection{Internet functions and operations}

Table 8 Functions relating to the Internet $\mathrm{N}=31$

\begin{tabular}{|c|c|c|c|c|c|c|c|c|}
\hline \multirow[b]{2}{*}{ FUNCTION } & \multicolumn{2}{|c|}{ No } & \multicolumn{2}{|c|}{ Yes } & \multicolumn{2}{|c|}{ Uncertain } & \multicolumn{2}{|c|}{ No response } \\
\hline & Count & $\%$ & Count & $\%$ & Count & $\%$ & Count & $\%$ \\
\hline Identify, find institutions home page & & & 31 & $100 \%$ & & & & \\
\hline Explore web thro home pages & & & 31 & $100 \%$ & & & & \\
\hline Use search history & & & 31 & $100 \%$ & & & & 31 \\
\hline Use a search engine & & & 31 & $100 \%$ & & & & \\
\hline Use navigation buttons & & & 30 & $96.8 \%$ & & & 1 & $3.2 \%$ \\
\hline Locate a source from an URL & & & 30 & $96.8 \%$ & I & $3.2 \%$ & & \\
\hline Create bookmarks & 1 & $3.2 \%$ & 30 & $96.8 \%$ & & & & \\
\hline Use bookmarks to access sites & 1 & $3.2 \%$ & 30 & $96.8 \%$ & & & & \\
\hline Down load file from a site & 2 & $6.5 \%$ & 28 & $90.3 \%$ & & & 1 & $3.2 \%$ \\
\hline Identify hypertext link & & & 27 & $87.1 \%$ & 1 & 1 & 3 & $9.7 \%$ \\
\hline
\end{tabular}

All of the subject librarians ( $3 \mathrm{I}$ or $100 \%$ ) could identify and find institutions homepage; explore Web through homepages; use search history; use a search engine. While $30(96.8 \%)$ could use navigation buttons; locate a source from an URL; create bookmarks; use bookmarks to access sites, 28 (90.3\%) download file from a site and $27(87.1 \%)$ identify hypertext link.

\subsubsection{Internet software or browsers}

Internet Explorer was used by 22 (70.6\%) of the subject librarians and 9 (29.4\%) used Netscape Navigator. 


\subsubsection{Networking functions and operations}

Table 9 Functions relating to networking $\mathrm{N}=31$

\begin{tabular}{lcccccc}
\hline \multirow{2}{*}{ FUNCTION } & \multicolumn{2}{c}{ No } & \multicolumn{2}{c}{ Yes } & \multicolumn{2}{c}{ Uncertain } \\
\cline { 2 - 7 } & Count & $\%$ & Count & $\%$ & Count & $\%$ \\
\hline Retrieve a document from server & 8 & $25.8 \%$ & 16 & $51.6 \%$ & 7 & $22.6 \%$ \\
Connect to file server & 8 & $25.8 \%$ & 15 & $48.4 \%$ & 8 & $25.8 \%$ \\
Save a document on server & 9 & $29 \%$ & 15 & $48.4 \%$ & 7 & $22.6 \%$ \\
Disconnect from server & 8 & $25.8 \%$ & 14 & $45.2 \%$ & 9 & $29 \%$ \\
Share files on network & 10 & $32.3 \%$ & 13 & $41.9 \%$ & 8 & $25.8 \%$ \\
\hline
\end{tabular}

Only $16(51.6 \%)$ of the subject librarians could retrieve a document from a server. While less than half ( 15 or $48.4 \%)$ could connect to server; save a document on the server, I 4 (45.2\%) could disconnect from server and I 3 (4I.9\%) share files on network.

4.3.II Set-up, maintenance and troubleshooting functions and operations

Table 10 Functions relating to setup, maintenance and troubleshooting $N=31$

\begin{tabular}{|c|c|c|c|c|c|c|c|c|}
\hline \multirow[b]{2}{*}{ FUNCTION } & \multicolumn{2}{|c|}{ No } & \multicolumn{2}{|c|}{ Yes } & \multicolumn{2}{|c|}{ Uncertain } & \multicolumn{2}{|c|}{ No response } \\
\hline & Count & $\%$ & Count & $\%$ & Count & $\%$ & Count & $\%$ \\
\hline Mack backup copies & 7 & $22.6 \%$ & 22 & $71 \%$ & 1 & $3.2 \%$ & 1 & $3.2 \%$ \\
\hline Protect and care for disks & 7 & $22.6 \%$ & 21 & $67.7 \%$ & 2 & $6.5 \%$ & 1 & $3.2 \%$ \\
\hline Connect peripheral devices & II & $35.5 \%$ & 16 & $51.6 \%$ & 3 & $9.7 \%$ & I & $3.2 \%$ \\
\hline Install and application & 9 & $29 \%$ & 15 & $48.4 \%$ & 7 & $22.6 \%$ & & \\
\hline Identify technical assistance & 10 & $32.3 \%$ & 15 & $48.4 \%$ & 6 & $19.4 \%$ & & \\
\hline Setup computer & 14 & $45.2 \%$ & 14 & $45.2 \%$ & 2 & $6.5 \%$ & I & $3.2 \%$ \\
\hline Protect against viruses & 9 & $29 \%$ & 14 & $45.2 \%$ & 8 & $25.8 \%$ & & \\
\hline Diagnose and correct problems & 10 & $32.3 \%$ & 13 & $41.9 \%$ & 7 & $22.6 \%$ & 1 & $3.2 \%$ \\
\hline Upgrade an application & 11 & $35.5 \%$ & 13 & $41.9 \%$ & 7 & $22.6 \%$ & & \\
\hline Clean computer, printer & 15 & $48.4 \%$ & 9 & $29 \%$ & 7 & $22.6 \%$ & & \\
\hline Identify operating environments & 16 & $51.6 \%$ & 6 & $19.4 \%$ & 9 & $29 \%$ & & \\
\hline
\end{tabular}

Most subject librarians ( 22 or $71 \%$ ) were able to make backup copies, while 21 (67.7\%) could protect and care for disks, $16(51.6 \%)$ could connect peripheral devices. Less than half ( 15 or $48.4 \%)$ could install an application; identify technical assistance, 14 (45.2\%) set-up computer; protect against viruses, 13 (4I.9\%) diagnose and correct problems; upgrade an application, 9 (29\%) clean computer, printer and six (19.4\%) identify operating environments.

In terms of software applications, with the exception of e-mail applications, Microsoft software was used extensively in all the libraries. However, with the merger between UN and UDW( forming the University of Kwazulu-Natal), standardisation may result in the use of one type of e-mail software across all the campus of the new merged institution. Subject librarians performed well in terms of the functions and operations for the following applications: file management, windows and keyboard, word processing, e-mail and Internet. However, they did not perform well in terms of the functions and operations for the following applications: spreadsheets, databases, presentations, networking and set-up, maintenance and troubleshooting. From the literature it is clear that subject librarians have to be familiar with all the above applications functions and operations in order for them to perform their roles effectively and efficiently in a demanding electronic environment that is constantly changing (Latham 2000; Marmion 1998). Given the fact that the majority of the subject librarians use a computer in the course of their duties or tasks, there is an under utilisation of these resources due to a lack of knowledge and skills. Therefore, the potential benefits and advantages of using such resources were not being realized.

\subsection{Problems the subject librarians faced in the use of ICTs}

- File management

Two (6.5\%) subject librarians experienced problems with ordering of files. While one (3.2\%) had problems with understanding the difference between drives and directories; understanding file management concepts; understanding the purpose of file management; understanding terminology and locating files using DOS.

- Windows and keyboard 
Three (9.7\%) subject librarians experienced problems with the system constantly changing. While two (6.5\%) had problems with the qwerty keyboard design and one (3.2\%) with operating without a mouse and aligning text.

- Word processing

Three (9.7\%) subject librarians experienced problems with migrating from Corel WordPerfect to Microsoft Word. While two (6.5\%) had problems with indenting in Microsoft Word and one (3.2\%) with setting tabs and inserting date and time.

- Spreadsheet

Five (16.1\%) subject librarians experienced problems such as no training, while three $(9.7 \%)$ forgot functions that were not used often and one (3.2\%) had problems with transferring data and formulas.

- Database

All 3 I (I00\%) subject librarians did not respond to the question relating to database problems.

- Presentations

Three (9.7\%) subject librarians experienced problems with a need for more training, while one (3.2\%) never used presentations; was unfamiliar with all the functions and found the clipart difficult to use.

- E-mail

Two (6.5 \%) subject librarians experienced problems with viruses; slow delivery and opening attachments, while one (3.2\%) had problems with using the GroupWise e-mail calendar.

- Internet

Three $(9.7 \%)$ subject librarians experienced problems with slowness, while two $(6.5 \%)$ had problems with outdated websites; access and one (3.2\%) with sites that disappeared.

- Networking

Four (12.9\%) subject librarians experienced problems with a lack of knowledge, while two (6.5\%) had problems with slowness of the network and one (3.2\%) with server downtime.

- Set-up, maintenance and troubleshooting

One (3.2\%) subject librarian experienced problems with keeping pace with change; support from ITD (Information Technology Division) staff was not prompt; understanding computer jargon; ignorance; lack of training and a lack of knowledge and understanding.

Unfortunately, a majority of the subject librarians did not respond to the question about problems they had experienced in each of the above sections. It should therefore not be assumed that most librarians had no problems as the quantitative data may suggest. The few who indicated problems experienced them as a result of lack of knowledge, understanding and training.

\subsection{The subject librarians ICT training needs}

\subsection{File management training}

More than half of the subject librarians $20(64.5 \%)$ had no formal training in file management. Of the subject librarians six (19.4\%) UN received file management training at an introduction to Windows course, two (6.5\%) at a UDW course and one (3.2\%) an A+ course; DOS file management course and PC engineering course.

\subsubsection{Windows and Keyboard training}

Less than half of the subject librarians (I lor 35.5\%) had no formal training in windows or keyboard operations. Of the subject librarians 9 (29\%) received windows and keyboard training at a UN introduction to Windows course, two (6.5\%) at a UZ course and one (3.2\%) at a UDW course; an ICDL module; Computer programming course; End-user computing course; $A+$ course and Windows 95 course.

\subsubsection{Word processing training}

Less than half of the subject librarians ( 13 or $41.9 \%$ ) had no formal training in word processing. Of the subject librarians nine $(29 \%)$ received word processing training at a UN Word introductory course, four (I2.9\%) a UN WordPerfect introductory course, and three $(9.7 \%)$ a UZ Word introductory course and one (3.2\%) an ICDL module.

\subsubsection{Spreadsheet training}

More than half of the subject librarians ( 21 or $67.7 \%$ ) had no formal training in spreadsheets. Of the subject librarians five (16.1\%) received spreadsheet training at a UN Excel introductory course, two (6.5\%) at an ICDL module and one (3.2\%) a Windows 95 course. 


\subsubsection{Database training}

Most of the subject librarians ( 25 or $80.6 \%$ ) had no formal training in databases. Only one (3.2\%) had attended an ICDL module for database training.

\subsubsection{Presentations training}

Less than half of the subject librarians (14 or $42.5 \%)$ had no formal training in presentations. Only 14 (45.2\%) of the subject librarians attended a UN PowerPoint introductory course while one (3.2\%) attended a UN Corel Presentations course and an ICDL module.

\subsubsection{E-mail training}

More than half of the subject librarians (2I or $67.7 \%$ ) had no formal training in e-mail. Only seven (22.6\%) of the subject librarians at the UN had attended a GroupWise introductory course.

\subsubsection{Internet training}

More than half of the subject librarians (2lor 67.7\%) had no formal training in the Internet. Of the subject librarians five ( $16.1 \%)$ received Internet training at a UN Internet introductory course, two $(6.5 \%)$ at a UDW course and one (3.2\%) at a UZ course.

\subsubsection{Networking training}

Most of the subject librarians (27 or $87.1 \%$ ) had no formal training in networking. Only two (6.5 \%) attended a Networking introductory course and one (3.2\%) a UDW course.

\subsection{Set-up, maintenance and troubleshooting training}

Most of the subject librarians ( 26 or $83.9 \%$ ) had no formal training in the set-up, maintenance and troubleshooting of computers. Only two (6.5\%) attended a computer college course while one (3.2\%) attended an A+ course and a UZ course.

Observedly, there is a general lack of ICT training. It can be argued that this lack of training would influence the subject librarians' level of ICT knowledge and skill. There were, however, exceptions to this observation. Even though there was a lack of formal training for file management, windows and keyboard, word processing, e-mail and the Internet, the subject librarians' level of knowledge and skill were high for these applications. Also, in examining the courses attended by subject librarians, most of these courses were introductory courses; none of the subject librarians had attended intermediate or advanced courses. Perhaps and most significantly, relating to training, is that two of the institutions, the UN and the UZ provided training for the ICDL yet only three subject librarians had obtained an ICDL. Also, with the pending merger between the UN and UDW(the two universities merged since 2004) it could be argued that eventually training for the ICDL would be available to UDW once the institutions had merged. Furthermore, only I6 (5I.6\%) of the subject librarians were aware that their institutions provided training for the ICDL. Generally, it could be argued that there was a lack of knowledge regarding the availability and benefit of the ICDL amongst the subject librarians.

\section{Conclusion and recommendations}

The survey of $3 \mathrm{I}$ subject librarians resulted in several significant findings. The study was able to establish the level of ICT knowledge and skills among the subject librarians and to make recommendations regarding the addressing of problems that were revealed. As was to be expected the majority of the subject librarians used a computer in the course of their duties or tasks at work. The findings of the study showed that subject librarians generally do not have the knowledge to explore and take advantage of the opportunities technology creates, nor did they have the skill or ability to perform the applications functions and operations described above effectively. In conclusion, by identifying the problems that subject librarians face in the use of ICT it is evident from the findings that the majority of these problems were as a result of a lack of understanding, knowledge, skill, and above all, as discussed above, a lack of training. Therefore, in an attempt to remedy this situation, the study made the following two broad recommendations with regard to education and staff training and development.

\subsection{Education}

Library schools should provide a curriculum that is balanced in the sense that it provides for an education in traditional librarianship as well as ICT knowledge and skills. With regard to the ICT knowledge and skills education, such an education must be user centred, and ICT must be viewed as a means not an end to promote a quality, efficient and effective service to library users. Also, such a curriculum must provide for continuing education so that librarians can update their ICT knowledge and skills to keep pace with ever changing technological developments. Where feasible library schools can link with existing higher qualification options like the ICDL, and recommend them to candidates for continuing education. 


\subsection{Staff training and development}

Library managers and supervisors in all the libraries under study need to realize the value of staff development and training for their library. Management should ensure all their staff understand and are able to cope with changes that have resulted from technological developments. The magnitude of change due to technological developments suggests that libraries have to devote greater resources to staff training and development. Library managers will have to make a commitment to staff training and development to ensure that staff has the necessary ICT knowledge and skills to work effectively in an environment that is demanding and rapidly changing.

\section{References}

Bluck, R. 1996. Staff development for subject librarians. In Oldroyd, M. (ed.) Staff development in academic libraries: present and future challenges. London: Library Association : 94-106.

Chisenga, J. and Rorissa, A. 200I. Libraries and ICT: a review of global trends and the state of the art in Africa. Paper prepared for the Second Meeting of the Committee on Development Information (CODI), Addis Ababa, Ethiopia, 4-7 September.

Computer Society of South Africa. 2002. International Computer Driving License. Retrieved on 19 January 2005 from http:// www.cssa.org.zal

ECDL Foundation. 1999. European Computer Driving Licence: syllabus version 3.0. Dublin: ECDL Foundation Ltd.

Farley, T., Broad-Preston, J and Hayward, T. 1998. Academic libraries people and change: a case study of the 1990s. Library Management, 19(4):238-25I.

Krissoff, A. and Konrad, L. 1998. Computer training for staff and patrons. Computer in Libraries, I8(I):28-3I.

Latham, J. 2000. The world online: IT skills for the practical professional. American Libraries, 3I (3):40-42.

London, J. 2002. E-mail to author. 3 Dec.

Marmion, D. 1998. Facing the challenge: technology training in libraries. Information Technology and Libraries, 17(4):216-218.

Saunders-McMaster, L. 1997. The 'coolest' job in the library. Computers in Libraries, 17(2):37.

Van Vliet, P. J. A., Kletke, M. G and Chakraborty, G. 1994. The measurement of computer literacy: a comparison of selfappraisal and objective tests. International Journal of Human-Computer Studies, 40:835-857.

Viljoen, J. H. and Underwood, P. G. 1997. Total quality management in libraries: fad or fact? South African Journal of Library and Information Science, 65(I):46-52.

Woodsworth, A. 1997. New library competencies. Library Journal, I22(9):46.

Zhou, Y. 1994. Analysis of trends in demand for computer literacy for librarians in academic and public libraries from 1974 to 1989. Ph.D. diss. Urbana-Champaign: University of Illinois.

\section{Endnote}

I. Copy of the survey is available from the author.

2. The University of Durban Westville (UDW) and the University of Natal (UN) merged in 2004 to form the University of KwaZulu-Natal(UKZN).

3. Technikon means University of Technology or Institute of Technology (such name change also occurred from 2004). 